\title{
Study on the role of the accident statistics in the design of coal mine safety signs
}

Accident statistics is an important basis in designing coal mine safety signs. In this paper, we study the process and feasibility for accident statistics as the design basis of the coal mine enterprise safety signs. This paper comes into a conclusion of unsafe actions which cause the accident can be divided into two categories: illegal action and error action. Illegal action could be subdivided into habitual illegal action and accident illegal action, while error action could be subdivided action into skills, decisionmaking and physiological perceptual action. In this paper, we specifically analyze five coal mine accident cases as examples, in order to conclude unsafe actions and unsafe states in every case. Specifically, unsafe acts are: bolt pretightening does not reach the designated position, sitting on the belt, no remote operating point column, maintenance without power cuts and operating under pressure. In addition, these unsafe acts lead to relative unsafe states, which are insufficient bolt pressure, point column instability, machine charging electricity and hydraulic pipe under pressure? Finally, these unsafe states become causations of accidents. Based on statistical analysis, we found out illegal actions of coal mine accident cases and specifically designed five safety signs, which are 'bolt must be preloaded in place', 'be careful of the column', 'ban to sit on belts', 'forbidden pressing operation' and 'maintenance must be power outages'.

Keywords: Accident statistics, coal mine, safety signs, design, effect

\subsection{Introduction}

$\mathrm{R}$ esearch on safety signs started from 1940s, large amount of work took place in 1960s [1]. The United States, Britain, Germany, Japan, France, Russia and the international organization for standardization (ISO) have established a series of standards related to safety signs $[2,3]$. Countries attached great importance to the research of safety signs, noticed the key role of safety sign to enterprises. Then they began to overall plan safety signs in roads and buildings,

Messrs. Iang Wei and Xiang Yuan-chi, China University of Mining \& Technology (Beijing): Faculty of Resources \& Safety Engineering, Ding No. 11 College Road, Haidian District, Beijing, Postal code 100083, China. E-mail: jiangwei678@126.com / xiangyuanchi@126.com unified safety signs recognition and its carrier forms, and strived to make enterprise's environment and production as a whole $[4,5]$.

Research on safety signs' various aspects of properties are numerous, such as colour, borders, and supplementary text [69]. It also contains the work environment and organizational environment of safety signs $[10,11]$, types of safety signs [12, 13], presentation forms of safety signs [14], cognitive demands $[15]$ and so on.

In terms of the effectiveness of safety signs, some scholars regard safety sign's ability of drawing people's attention as the effectiveness of as the standard of effectiveness [16-18]. Some scholars judge the management of a safety sign by a criterion of understandability, which means an understandable safety sign would be easier for people to remember and obey $[19,20]$. In addition, some scholars use safety sign's management level of risk to measure its effectiveness [21-23]. Moreover, some researchers investigate whether participants act in compliance with safety management directly $[24,25]$.

The common features of national safety marks are:

1. The types and meanings of safety signs are unified gradually in different countries. Safety signs are classified into prohibition signs, warning signs, instruction signs and indication signs. But in Japan, because of its national conditions, the types of safety signs are almost square or rectangle. Besides Japan the geometry in other countries is consistent with ISO. All countries design specific symbols inside the consistent geometry figures according to their actual needs.

2. Safety colours are gradually unified. Safety colours include red, blue, yellow, green, and their meanings are same with provisions of ISO. Moreover, Japan has orange which does not exist in other countries.

3. Safety standards are modified and abolished according to specific situations and needs in each country. The review cycle is commonly $3-5$ years, while the longest period would be no more than five years, striving to continuously improve.

4. Former studies about safety signs mainly focus on colour, colour assortment, facilities construction, appearance, size and material, etc. 
Therefore, there would be a few researches on the design basis of safety signs, especially the domain of coal mine safety signs. The underground of coal mine is complex; as a result, it is necessary to design safety signs according to the actual situation of the coal mine. Therefore, it would be important to research the design basis of coal mine safety signs.

\subsection{The design basis}

In terms of the design basis of coal mine safety signs, literature [26] shows the specific design basis research. From Fig.1, it could be found that the design basis of the coal mine safety signs are national standard of safety signs, "three violations" statistics, accident statistics, the hidden statistics, other industry safety signs studies and visual management. Due to space limitations, this paper mainly focuses on specific application process of accident statistics in the coal mine safety signs designing.

\subsection{Accident statistics and analysis}

3.1 THE PURPoSES OF ACCIDENT STATISTICS ANALYSIS

Unsafe actions and unsafe states could be found via accident analysis, and further refining. In order to prevent accidents, it is important to display the unsafe actions and unsafe conditions through safety signs, then place signs at the job site to remind workers.

Purposes achieved by accident analysis:

1. Identify which section, post and staff are easy to cause accident, make sure the basis of accident prevention.

2. Make clear recognition of dangerous and harmful factors in the system and the damage forms under the trigger condition.

3. To be one of the important work in enterprise security management, accident statistics and analysis reflect their importance through staff's safety education. The accidents are real invents actually occurred around workers, which are different from persuading methods like rules, regulations and other safety education. As an education form, real accident cases are diversified, vivid and specific, and they are more infective and targeted on education workers. Different types of accident case education could improve workers' safety habits and promote their safety awareness. It also provides a powerful tool of security management for security managers. After accident case analysis and summary, it is more likely to catch the common and nature of accidents. From the causation of the accidents, it is easier to implement enterprise security education and reduce the incidence of accidents and risk of systems.

\subsection{UNSAFE BEHAVIOUR IN THE ACCIDENT}

The direct causes of accidents would be human unsafe actions and unsafe conditions [27]. According to Heinrich's accident statistics and studies, it is found that 80 per cent of accidents are caused by unsafe human behaviour, while only $20 \%$ of accidents are caused by unsafe condition. Therefore, study of accidents greatly depends on the research of unsafe behaviour's forms and how it works.

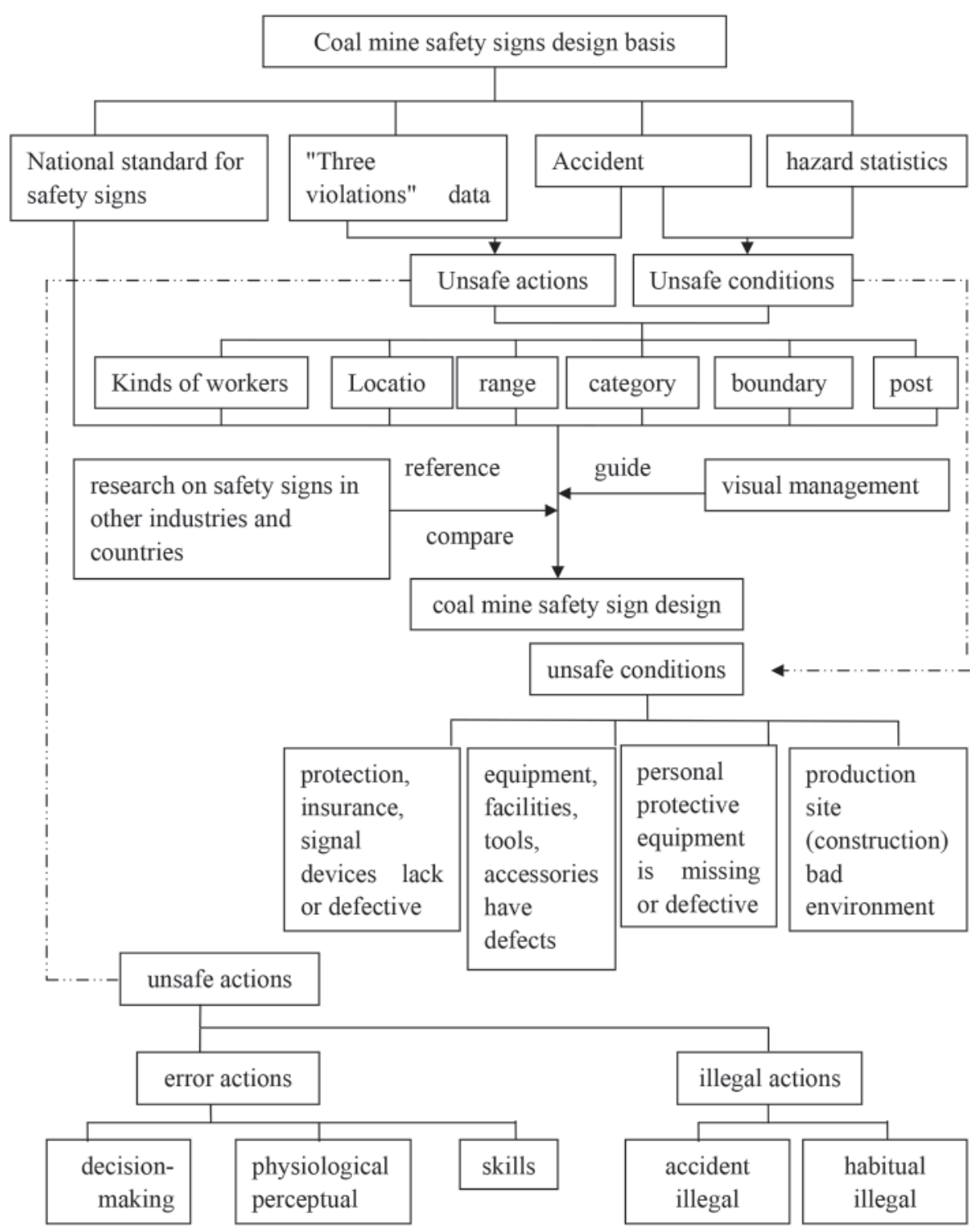

Fig.1 Safety signs design drawing for coal mine 
Accidents caused by unsafe acts could be divided into two types: (1) Unsafe behaviours trigger dangerous and harmful factors. In this case, the accidents usually do not happen immediately. But after a certain amount of time and accumulation, the hazard would occur in some way; (2) Unsafe behaviours directly cause accidents. According to the law of Heinrich, unsafe behaviour in most cases will not immediately cause accidents, which to a certain extent encourages the workers' unsafe operation. However, the risk would increase with the increasing of unsafe behaviour, eventually leading to the accident.

Unsafe acts are related to workers' professional quality, work habits, safety awareness and other factors. To analyze the causes of unsafe behaviour, it needs to make an overall consideration of the person's psychology, education, safety knowledge, safety management system, operation safety atmosphere and other factors. These complex factors lead to the variety of safety behaviour [28].
With a further research, the author found that unsafe actions can be subdivided into error action and illegal action. Error movement is a wrong action, which is not a conscious action in order to violate operation regulations. Illegal action is a conscious action in violation of the operation regulations. Error action is subdivided into skill, decision-making and physiological perceptual action. Skill error action refers to an error caused by a worker's lack of this skill. Decision-making error action occurs when a worker lacks necessary knowledge which lead to wrong decisions and error action; physiological and perceptual error action occurs because of physical reasons. Workers do not perceive danger or risk and this causes the wrong action. Illegal action could be divided into habitual illegal action and accident illegal action, which is shown in Fig.1.

Because of above reasons, it is necessary to make a systematic research on the enterprise accidents in order to control the personnel unsafe behaviours and prevent accidents.

TABle 1: CoAl mine ACCident CASES ANALysis

\begin{tabular}{|c|c|c|c|c|}
\hline & The process of the accident & Unsafe condition & Unsafe act & \\
\hline 1 & $\begin{array}{l}\text { On March } 11 \text { th night shift in a mine transport } \\
\text { tunnel, steering group carried out safety } \\
\text { inspection and found that some roof bolt pre- } \\
\text { tightening work was not up to the requirements, } \\
\text { part of the bolt installation angle didn't not } \\
\text { meet the requirements. }\end{array}$ & $\begin{array}{l}\text { (1) the bolt pre- } \\
\text { tightening is not in } \\
\text { place; (2) the anchor } \\
\text { point does not meet } \\
\text { therequirements }\end{array}$ & $\begin{array}{l}\text { Bolt set does not meet } \\
\text { the requirements }\end{array}$ & $\begin{array}{l}\text { Illegal } \\
\text { action }\end{array}$ \\
\hline 2 & $\begin{array}{l}\text { On the June } 8 \text { excavation team worker Lee sat } \\
\text { on the belt conveyor, his head stroke against the } \\
\text { escape platform when he was } 100 \text { meters away } \\
\text { from the belt conveyor tail, causing a skull } \\
\text { fracture and hyperextension cervical dislocation. } \\
\text { As a result, he fell into the underlying machine } \\
\text { tape of the running belt conveyor, and died after } \\
\text { dragged to the rear tail section } 4 \text { bars. }\end{array}$ & & $\begin{array}{l}\text { Take a running belt } \\
\text { conveyor }\end{array}$ & $\begin{array}{l}\text { Illegal } \\
\text { action }\end{array}$ \\
\hline 3 & $\begin{array}{l}\text { On March } 17 \text { th, the working face of mine, } \\
\text { monitor on duty arranged Huang, Xu and Meng } \\
\text { to transfer frame. Huang's left hand was hit by } \\
\text { pillar slip when using single column adjustable } \\
\text { shelf. As a result, Huang's left hand soft tissue } \\
\text { was lacerated, and his second metacarpal bone } \\
\text { has open fracture. }\end{array}$ & $\begin{array}{l}\text { Point column } \\
\text { instability }\end{array}$ & $\begin{array}{l}\text { (1) not latch the stigma } \\
\text { when using single point } \\
\text { to adjust bracket; } \\
\text { (2) no use remote } \\
\text { operation }\end{array}$ & $\begin{array}{l}\text { Illegal } \\
\text { action }\end{array}$ \\
\hline 4 & $\begin{array}{l}\text { When Zhang replaced broken tube stent, he did } \\
\text { by himself. He did not stop the liquid closing } \\
\text { bracket liquid-in valve, also didn't arrange person } \\
\text { to help him. He demolished fluid pipe under } \\
\text { pressure with force. After the head of the u- } \\
\text { shaped being pinned out, liquid pipe began to } \\
\text { break around, and hit Zhang's leg. }\end{array}$ & $\begin{array}{l}\text { Removing the tube } \\
\text { when it has pressure }\end{array}$ & $\begin{array}{l}\text { (1) operate alone; } \\
\text { (2) non-stop fluid inlet } \\
\text { and shut off valve; } \\
\text { (3) not arrange a person } \\
\text { to help hand bracket }\end{array}$ & $\begin{array}{l}\text { Illegal } \\
\text { action }\end{array}$ \\
\hline 5 & $\begin{array}{l}\text { On February 3rd, scraper conveyor belt lane was } \\
\text { out of electricity in a mine developing zone. } \\
\text { Electrician Lee repaired switch, but he didn't cut } \\
\text { power supply. In the process of maintenance, } \\
\text { Lee accidentally caused short circuit of power } \\
\text { supply, making it sparked, and burned Lee's hand. }\end{array}$ & $\begin{array}{l}\text { Scraper conveyor } \\
\text { charged when it was } \\
\text { repaired }\end{array}$ & $\begin{array}{l}\text { Open the switch cover } \\
\text { of scraper conveyor with } \\
\text { power }\end{array}$ & $\begin{array}{l}\text { Illegal } \\
\text { action }\end{array}$ \\
\hline
\end{tabular}


Table 2: Coal Mine Safety signs design

\begin{tabular}{ll|l}
\hline Nos. Meaning & Solt must \\
be preloaded \\
in place
\end{tabular}

3.3 The ROLE OF ACCIDENT ANALYSIS IN SAFETY SIGNS DESIGNING

Through the statistic and analysis of accidents, not only could we clearly find out all kinds of accident conditions and safety management situations in an enterprise in a certain period, but we also can make sure factors that cause accident easily, behaviours apt to trigger danger, the kinds of unsafe behaviours, categories of accidents, etc. The statistic and analysis of accidents could intuitively identify hazards in workplace, risk factors, dangerous substances, and unsafe behaviours of workers.

The objective to design and set up safety signs is to reduce the unsafe behaviour and the occurrence of the accident by using hazard warning and behaviour guidance. This needs to have well understanding about unsafe behaviour of workers and risk factors within the system. Accident statistics and analysis is provided for these contents for safety signs. Through the statistical analysis of the accident, we can make clear the content, position and method of the safety signs.

At the same time, statistic and analysis of accidents also provide the basis for the design of safety signs. Under different industries and operation environment, the existence conditions of the risk factors and the specific manifestations of unsafe behaviour are different. Through the coal mine accident statistics, we can have a certain understanding on the coal mine safety signs design condition and coal mine workers' safety knowledge, safety consciousness. These contribute to design and set safety signs more specifically. Therefore, the statistics and analysis of accidents is one of the important basis of coal mine safety signs design.

\subsection{Specific application process of accident analysis in coal mine safety signs designing}

We would analyze accidents according to the following five coal mine accidents, therefore the design of safety signs could target on unsafe actions and unsafe states. These accident cases are retrieved from the Internet.

From the five accidents depicted in Table 1, it could be concluded that large amount of unsafe conditions are caused by people's unsafe actions.

After identifying unsafe actions and unsafe conditions in the accident, the corresponding safety signs could be well designed. Here are five corresponding safety signs designed by the analysis of five cases.

\section{0 Conclusions}

From the description and analysis above, the following conclusions could be obtained:

(1) Accident statistics is an important basis of coal mine safety signs design.

(2) Unsafe actions which cause the accident, could be subdivided into illegal action and error action. Illegal actions can be divided into habitual illegal action and accident illegal action, error actions can be divided into skills, decision-making and physiological perceptual action.

(3) This paper specifically analyses five coal mine accident cases as examples, drawing conclusion of the unsafe actions and unsafe states in five cases. In which unsafe acts are: bolt pre-tightening does not 
reach the designated position, sit on the belt, no remote operating point column, maintenance without power cuts and operating under pressure. In addition, these unsafe acts lead to corresponding unsafe states, which are insufficient bolt pressure, point column instability, machine charging electricity and hydraulic pipe under pressure. Finally, these unsafe states become causations of accidents.

(4) This paper designs five safety signs specifically for the illegal actions in the five coal mine accident cases according to the statistical analysis, which are 'bolt must be preloaded in place', 'be careful of the column', 'don't sit on belts', 'no operation with pressure' and 'maintenance with cut power'.

\subsection{Acknowledgment}

This work is supported by National Natural Science Foundation of China - study on the improvement of safety culture concept, elements and quantitative measurement method (project number: 51504260).

\section{0 References}

[1] Zhu Zhaohua, Guo Zhenlong (2004): The origin of the safety sign and safety colour [J]. Modern occupational safety, 10:64

[2] Beijing Municipal Institute of Labour Protection. Safety colours and safety signs national standard data compilation [M]. Beijing: The labor press,1982.5

[3] Administration of Quality and Technology Supervision of Guangdong Province. ISO general public information symbol standard. [EB/OL]. http:// www.gdqts.gov.cn/zjxx/zsyd/bzh/200810/ t20081015_1745.html,2008-4-10

[4] The Official Highway Code. Edition The Stationery Office 2007 ISBN 978011552814 9[S]. Highway Code online versionwww.direct.gov.uk/highwaycode

[5] Signpost to the Health and Safety (Safety Signs and Signals) Regulations. Leaflet INDG 184 HSE Books 1996 (single copy free or priced packs of 15 ISBN 978 071761139 3)[S].www.hse.gov.uk/pubns/indg 184.htm

[6] Christopher B. Mayhorn, Michael S. Wogalter, Kenneth R. Laughery. (2014): Special issue on warnings: Advances in delivery, application, and methods Original Research[J]. Applied Ergonomics. 1267-1271.

[7] Carter, E.C and Carter, R.C.(1981): Colour and conspicuousness [J]. Journal of the Optical Societv of America, 1:72N729.

[8] Gao X.W. L. Podladchikova, D. Shaposhnikov, K. Hong and N. Shevtsova. (2006): Recognition of traffic signs based on their colour and shape features extracted using human vision models $[\mathrm{J}]$. J. Vis. Commun. Image R. 17 :675-685.
[9] Braun,C.C., Kline, P.B. and Claton Silver, N. (1995): The influence of colour on warning label signs[J] International Journal of Industrial Ergonomics, 15:179-187.

[10] McDougall, Curry, M.B, de Bruijn, O. (1999): Measuring symbol and icon characteristics: norms for concreteness, complexity, meaningfulness, familiarity, and semantic distance for 239 Symbols [J]. Behav. Res. Methods, Instruments, Comput. 31:487-519.

[11] Brown, S. P. and Leigh, T. W. (1996): A new look at psychological climate and its relationship to job involvement, effort, and performance [J]. Journal of Applied Psychology, 81:358-368.

[12] Ursic M. (1984): The Impact of Safety Warnings on Perception and Memory[J].Human Factors: The Journal of the Human Factors and Ergonomics Society.26(6), 677-682.

[13] Hellier et al. (2000): On the stability of the arousal strength of warning signal words[J]. Applied Cognitive Psychology, 14(6): 577-592.

[14] Collins, B.L. and Lerner, N.D. (1982): Assessment of Fire-Safety Symbols[J]. Human Factors: The Journal of the Human Factors and Ergonomics Society, 24(1):75084.

[15] Conzola,V. C. and Klein, K. W. (1998): Need for cognition: an individual differencesApproach to understanding warning effectiveness [A]. In: Proceedings of the Human Factors Society 42nd Annual Meeting [C]. Human Factors Society, Monica, 811-815.

[16] Kalsher, M.J., Wogalter, M.S., Pucci,S., Racicot, B.M. (1994): Enhancing the perceived readability of pharmaceutical container labels and warning: the use of alternative designs and pictorials $[\mathrm{J}]$.Proceeding of Human Factors Society 38th Annual Meeting. Human Factors Society, Santa Monica,CA,1994:384-388

[17] Kalsher, M.J.,Wogalter, M.S., Racicot, B.M. (1996): Pharmaceutical container labels and warnings: preference and perceived readability of alternative designs and pictorials[J]. Int. J. Ind Ergonomics, 18:8390

[18] Young, S.L.,Wogalter, M.WS. (1998): Relative importance of different verbal components in conveying hazard-level information in warning $[\mathrm{J}]$. Proceedings of the Human Factors and Ergonomics Society 42nd Annual Meeting. Human Factors and Ergonomics Society, Santa Monica, CA, 1998:10631067

[19] Ringseis E L, Caird J K. (1995): The comprehensibility and legibility of twenty pharmaceutical warning pictograms[J]. Proceeding of the 39th Annual Meeting of Human Factors and Ergonomics Society, 974-978 
[20] Wogalter, M.S., Rashid, R. (1998): A border surround a warning sign affects looking behaviour:a field observational studu[J]. In: Proceeding of the Human Factor and Ergonomics Society 42nd Annual Meeting. Human Factor and Ergonomics Society, Santa Monica, CA, 1628

[21] Adams, A.S., Edworthy, J. (1995): Quantifying and predicting the effects of basic text display variables on the perceived urgency of warning labels: tradeoffs involving font size, border weight, and colour[J]. Ergonomics, 38:2221-2237

[22] Chapanis, J.T. (1994): Hazard associated with three signal words and four colours on warning signs $[\mathrm{J}]$. Ergonomics, 37:265-275

[23] Braun, C.C., Sansing, L., Kennedy, R.S., Silver, N.C. (1994): Signal word and colour specifications for product warning:an isoperformance application[J]. In: Proceeding of the Human Factors Society 38th Annual Meeting. Human Factors and Ergonomics Society,
Santa Monica,1104-1108

[24] Dingus, T.A., Hathaway, J.A., and Hunn, B.P. (1991): A most critical warning variable: two demonstrations of the power effects of cost on warning compliance[J]. In Proceedings of the 35th meeting of human factors society. Santa Monica, CA,1034-1038

[25] Leonard, S.D., Karnes, E.W., Schneider, T. (1999): Scale values for warning symbols and words[J]. Aghazadeh, $\mathrm{F}(\mathrm{Ed})$, Trends in Ergonomics/Human Factors. Elsevier, Amsterdam, 669-674

[26] Jiang Wei, Li Shibo, Zhu Zhiming, Zhang Dongqin. (2015): Study on design basis of the coal mine safety signs[J]. Safety in coal mine, 46, (10): 232-235

[27] Heinrich W H, Peterson D, Roos N. (1980): Industrial Accident Prevention [M]. New York: McGraw-Hill Book Company, 1980

[28] Fu Gui. (2003): Analysis on two kinds of safety management mode[J]. Safety management, 41-43.

\section{JOURNAL OF MINES, METALS \& FUELS}

SPECIAL ISSUE

$\mathrm{ON}$

\section{THICK SEAM MINING IN CHINA - AN UPDATE}

Price per copy

Rs.500.00; $£ 50.00$ or $\$ 80.00$

For copies please contact:

The Manager

Books \& Journals Private Limited

Moon Plaza (2A, 2nd Floor), 62 Lenin Sarani, Taltala, Kolkata 700013

e-mail: bnjournals@gmail.com; pradipchanda@yahoo.co.uk;

www.jmmf.info $\bullet$ Mob: +919239384829 